\title{
OVERVIEW
}

\section{Conservation and ecology of the neglected slow loris: priorities and prospects}

\author{
K. A. I. Nekaris ${ }^{1}$, Carly R. Starr ${ }^{2, *}$ \\ ${ }^{1}$ Oxford Brookes University, Nocturnal Primate Research Group, School of Social Sciences and Law, Oxford OX3 0BP, UK \\ ${ }^{2}$ Northern Gulf Resource Management Group, Mareeba, Queensland 4880, Australia
}

\begin{abstract}
Slow lorises Nycticebus spp. have one of the widest distributions of any nocturnal primate species, occurring in 14 Asian countries; yet, in terms of their taxonomy, ecology and distribution, they remain amongst the least known of any primate taxa. Eight species are now recognised; 5 of these have been listed in the IUCN Red List as Vulnerable or Critically Endangered, with 3 Not Assessed. Threats to these primates not only include habitat loss, but the illegal wildlife trade. Slow lorises are highly desired in traditional medicines, and as pets both nationally and internationally. In this Theme Section (www.int-res.com/journals/esr/esr-specials/conservationand-ecology-of-slow-lorises), we bring together 13 studies on several key topics. We present survey data from the Indonesian island of Java, from Malaysian Sabah on the island of Borneo, from northeast India and from Singapore. All of these studies concur that slow lorises occur at low abundance, but that, where they are left alone, they can also persist in anthropogenically modified habitats. We present novel data on the feeding ecology of slow lorises, reifying that these primates are obligate exudativores. Such data are vital for keeping lorises in captivity; in 3 studies, an exudate-based diet is shown to improve health and reduce behavioural abnormalities. We show that local knowledge can provide vital data regarding slow loris distribution and in helping with conservation programmes for these taxa. The illegal trade for slow lorises is consistently brought up as a threat, and another contribution shows that a similar trend is also occurring with their phylogenetic relatives in Africa, the pottos. We highlight several areas where more research is needed and provide suggestions to fill those gaps.
\end{abstract}

KEY WORDS: Primate conservation $\cdot$ Nycticebus $\cdot$ Perodicticus $\cdot$ Arctocebus $\cdot$ Loris $\cdot$ Illegal wildlife trade $\cdot$ Census techniques $\cdot$ Ethnozoology

\section{BACKGROUND}

Catastrophic forest decline coupled with a rampant illegal wildlife trade poses a serious threat to biodiversity in most Southeast Asian countries (Sodhi et al. 2010). The impact of these factors on mammalian groups has been stated broadly, but also studied for many taxa at a more specific level, especially for charismatic ones such as elephants (Wittemyer et al. 2014), tigers (Nijman \& Shepherd 2015) and orangutans (Cattau et al. 2014). To conserve such animals, many conservation organisations have attempted to

\footnotetext{
*Corresponding author: bpm@northerngulf.com.au
}

give these threats to biodiversity loss a 'face' that can be associated with it - such as golden lion tamarins for forest fragmentation, elephants for human wildlife conflict, or orang-utans for forest loss due to palm oil plantations (Dietz et al. 1994, Leader-Williams et al. 2000, Bandara \& Tisdell 2005).

The slow lorises Nycticebus spp. are another heavily threatened group of Asian mammals. Forest loss plays a role in the decline of these nocturnal primates, yet it is illegal trade that is rapidly devastating their numbers throughout their range (Shepherd et al. 2005, Starr et al. 2010a), and some organisations

() The authors 2015. Open Access under Creative Commons by Attribution Licence. Use, distribution and reproduction are unrestricted. Authors and original publication must be credited. 
have already begun to recognise slow lorises as the 'face' representing illegal wildlife trade. Slow lorises are used for multiple purposes in trade. In many Asian countries, they are considered to cure up to 100 ailments, and, as such, animals are caught and killed for their perceived medicinal value (Starr et al. 2010a). The pet trade in slow lorises thrives both nationally and internationally. Not only are they kept in private homes, but captive lorises are also used as 'photo-props', whereby tourists in bars, clubs and on beaches may take their photo with wild-caught animals. Until recently, these primates were virtually unknown to the general public, but in the last few years a phenomenon has grown around slow lorises on the Internet, where videos of mostly wild-caught and illegally obtained slow lorises kept as pets are viewed by millions. These 'cute' slow loris videos are among the most viewed wild animal videos on social networking sites, which, in turn, increases the desirability of owning a slow loris as a pet (Nekaris et al. 2013a). Despite the risk of such a platform, there is now great potential for harnessing this medium to raise awareness of the plight of slow lorises and for providing education to the public about the threat of the illegal wildlife trade. The appeal of these teddybear like primates with forward-facing eyes has the potential to create empathy, making slow lorises a suitable animal to put a 'face' to the increasing international threat of the illegal pet and photo-prop trade (Nekaris \& Campbell 2012).

It is the illegal trade that finally brought slow lorises to the attention of the conservation community. The large number of slow lorises observed in illegal trade has resulted in changes over the last $10 \mathrm{yr}$ in the way international bodies and organisations view slow lorises. In 2007, the genus Nycticebus was transferred to Appendix I of the Convention on International Trade in Endangered Species of Wild Fauna and Flora (CITES), precluding all international trade in the species, their parts, or their derivatives (Nekaris \& Nijman 2007). In 2008, the 5 then-recognised species were all listed as Vulnerable or Endangered on the IUCN Red List, whereas prior to that time the only 3 species recognised were listed as Near Threatened. In 2013, one new species of slow loris (the Kayan slow loris N. kayan) was described and 2 other earlier described forms (Sody's slow loris $N$. bancanus and Bornean slow loris $N$. borneanus) were elevated to the species level (Munds et al. 2013b). These 3 species still have to be formally assessed according to IUCN threat criteria, but, in 2013, a reassessment of the Javan slow loris $N$. javanicus concluded it should be considered as Critically Endangered (Nekaris et al. 2013c). All countries where slow lorises occur provide some level of legal protection for these species (Table 1), yet, in most of them, slow lorises continue to be traded openly, with little evident enforcement (Starr et al. 2010a, Nijman et al. 2014).

Illegal trade has a multitude of implications that highlight our lack of understanding of slow lorises in the wild. First, sparse data on the species' distribution and abundance make understanding the impact of trade challenging (Nekaris \& Nijman 2007). Secondly, a lack of ecological field data impedes optimum husbandry in captive facilities, which may be required for caring for rescued animals, as well as developing insurance populations. Information required includes basic data such as what to feed slow lorises, how to house them and knowledge of what type of habitat is best for releasing them (Streicher 2004). Thirdly, limited understanding of slow loris taxonomy confounds attempts to reintroduce these animals or hold them or breed them in captive facilities (Schulze \& Groves 2004). In this Theme Section, the first ever edited contribution dedicated to slow loris conservation, we attempt to fill some of these gaps and to highlight areas where further research is necessary.

Perhaps because of their nocturnal nature or their occurrence in areas where study is difficult due to nocturnal predators or human insurgence, the family Lorisidae remains amongst the least known of all the primates (Nekaris \& Bearder 2007), with only a handful of published studies in recent years (Fig. 1). Currently Lorisidae comprises 3 species of potto (Perodicticus), 2 species of golden potto or angwantibo (Arctocebus), and 2 species of slender loris (Loris), all of which probably contain unrevealed diversity, even at the family level (Pozzi et al. 2014). In terms of the slow lorises, 1 genus (Nycticebus) comprises a group of 8 currently recognized species that range in 14 Asian countries (Table 1) (Groves 2001, Munds et al. 2013b). Again, evidence for multiple genera and species within slow lorises is mounting, and revisions are expected (Nekaris \& Jaffe 2007, Pozzi et al. 2014). Morphologically unique (Fig. 2), the lorisids are characterised by large forward-facing eyes, a vice-like grip with a shortened second digit, a short tail, species-specific facial markings, and short woolly fur, a suite of characteristics that has long been of interest to morphologists (Ishida et al. 1992, Kingston et al. 2010, Nekaris 2014). Classified as arboreal slow climbers, lorises and pottos cannot leap, but instead bridge between gaps in the forest canopy and dense underbrush in tree fall zones (Sellers 1996). Despite their extreme arboreal adaptations, lorises and pottos 


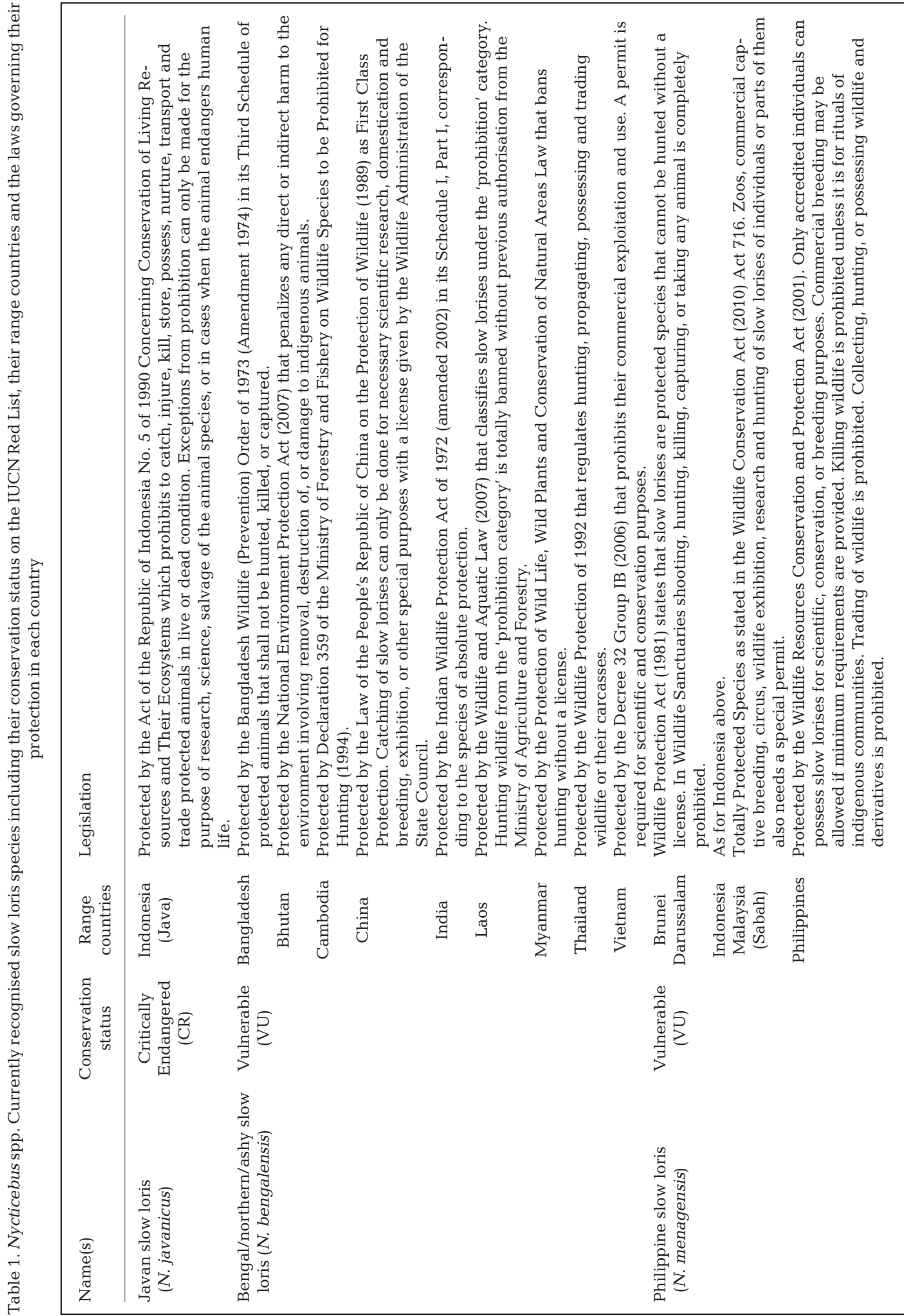




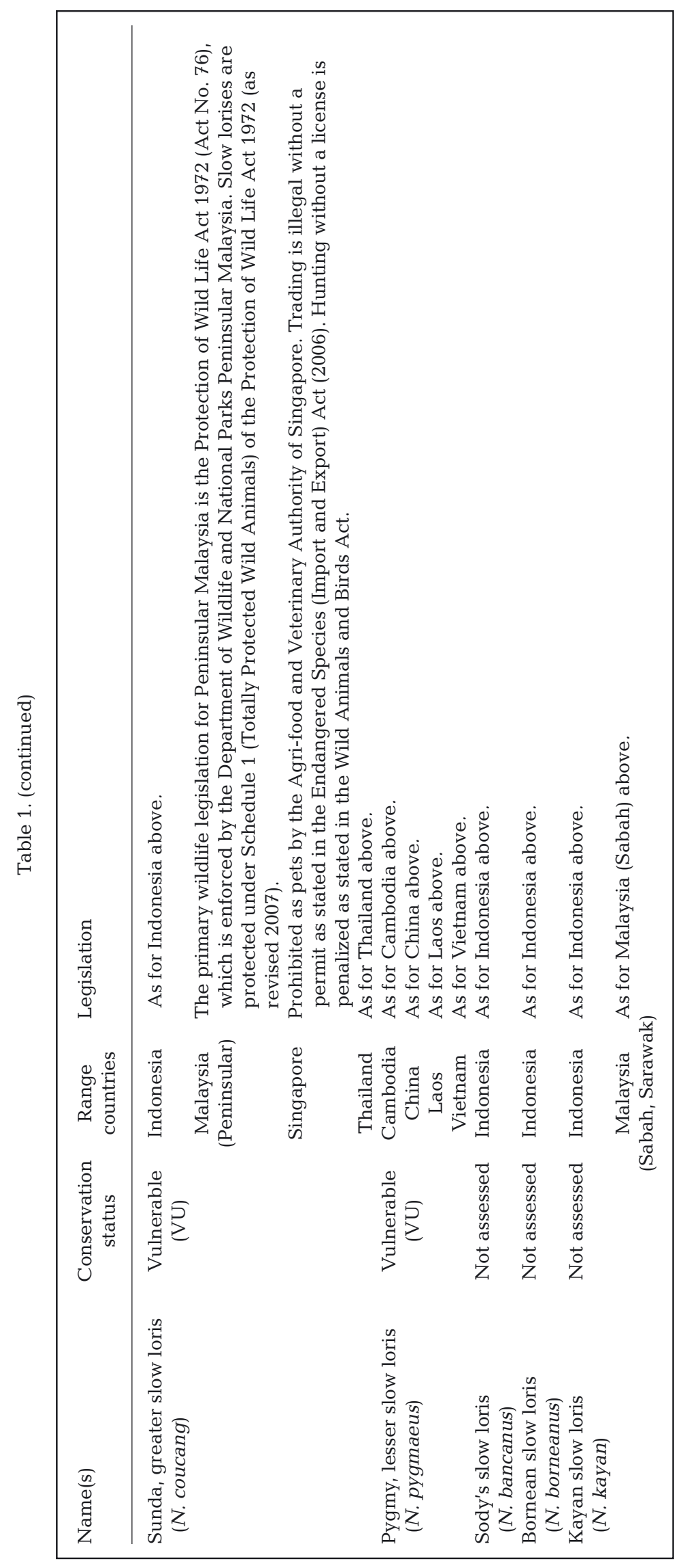

are found in numerous habitats, from primary forest to coastal forests, montane forests, disturbed agroforests and suburban gardens (Nekaris 2014). How these traits function ecologically is slowly being revealed based on several long-term field studies (Wiens 2002, Streicher 2004, Pimley et al. 2005, Nekaris 2006, Starr \& Nekaris 2013, Das et al. 2014, Rode-Margono \& Nekaris 2014) and a handful of short-term observations (e.g. Pliosungnoen et al. 2010, Swapna et al. 2010, Rogers \& Nekaris 2011).

Of all the lorisids, the number of studies of slow lorises has increased the most rapidly in recent years (Fig. 1), in part in response to their dire conservation status (Nekaris 2014). Slow lorises are relatively gregarious primates, living in pairs with 1 to 4 offspring, covering home ranges from 3 to 35 ha (Nekaris 2014). In terms of diet, slow lorises are gouging specialists, and their lower front teeth comprise a unique toothcomb that allows them to anchor their teeth into bark to produce holes from which exudates emerge and are licked by a long tongue (Nekaris et al. 2010, Streicher et al. 2012). The long tongue also facilitates consumption of nectar, whereas the toothcomb is related to another unique slow loris feature - they are the only venomous primates (Alterman 1995). By mixing oil from the brachial gland in their mouth, slow lorises use their powerful toothcomb to inject venom into their victims (usually another slow loris), or lick their fur with the compound, seemingly to reduce ectoparasites (Nekaris et al. 2013b, Grow et al. 2015).

Locating suitable field sites to study slow loris ecology is often challenging. Barrett (1981), who attempted the first systematic study of slow lorises in the wild, spent $>15$ mo before finding a study site, at which he still could not easily see or catch slow lorises. Wiens (2002) spent several periods in Malaysia over 4 yr simply attempting to trap slow lorises in order to radio collar them, and managed to observe animals for just $600 \mathrm{~h}$, and with many individuals being followed continuously for $<3$ mo. Starr et al. (2010b) spent 12 mo surveying both for the Bengal slow loris $N$. bengalensis and the pygmy loris $N$. pygmaeus before finding a site with enough animals to study; even in 


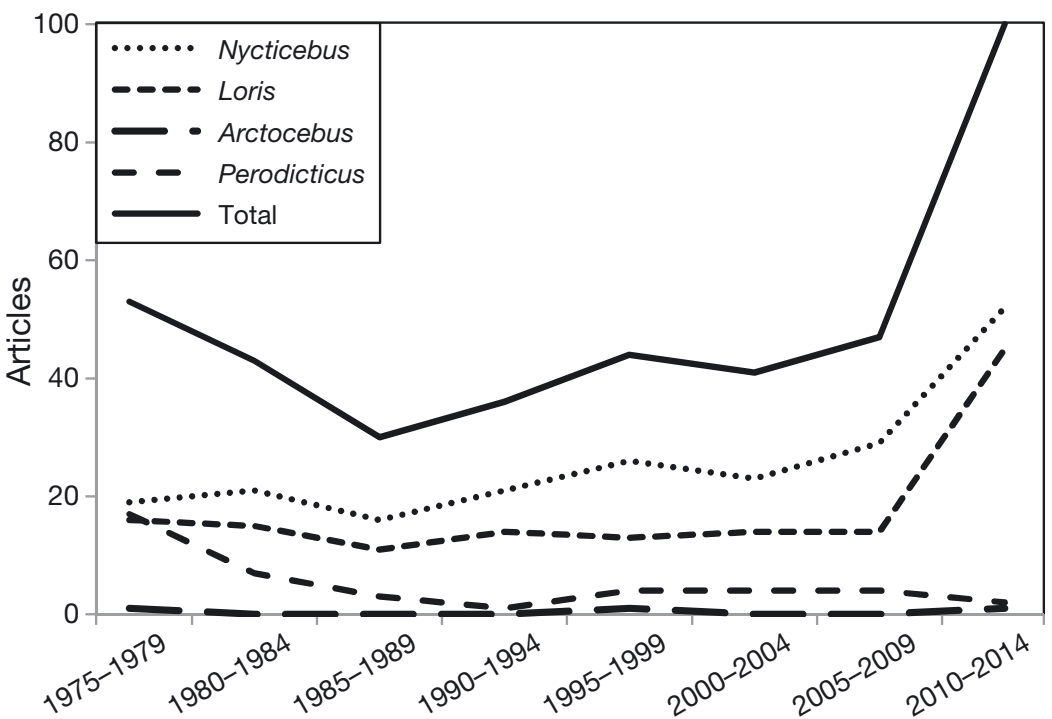

Fig. 1. Lorisidae remain amongst the least-studied primate family. Based on a Web of Science search since 1975 of any type of publication dealing with these primates (including morphological, molecular and captive work), on average only 6 publications per year per genus have been published, and for some genera and species, still virtually nothing is known
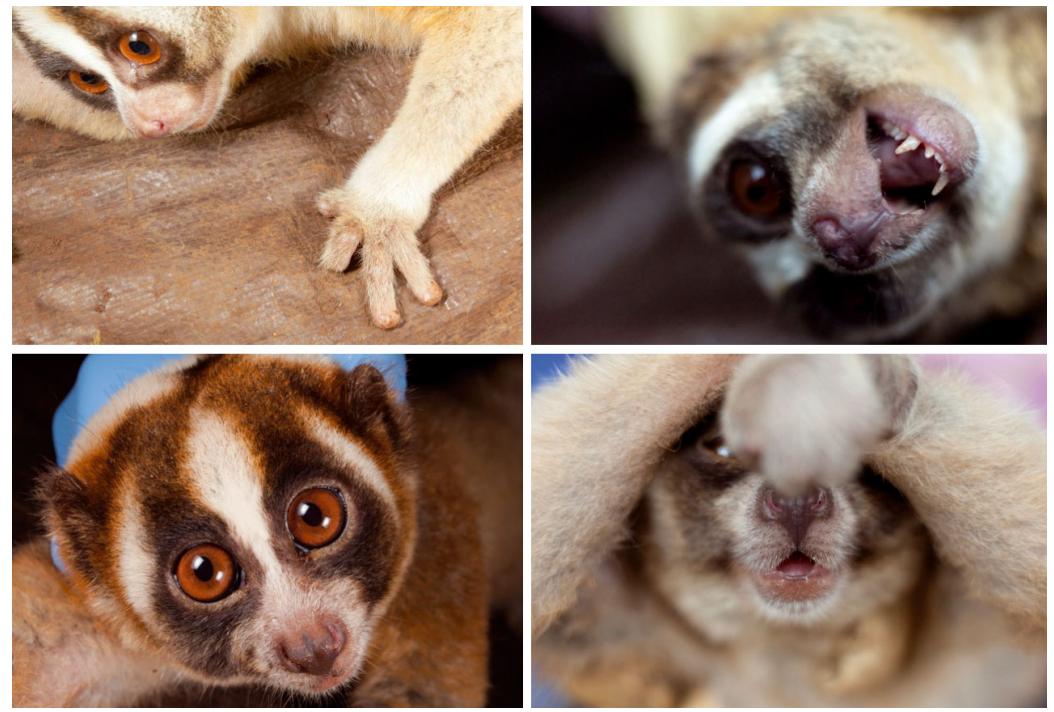

Fig. 2. Nycticebus javanicus. Slow lorises display numerous unique morphological characteristics. Some of these, illustrated by the Javan slow loris, include (clockwise from top left): a strong pincer-like hand with reduced second digit; stout sharp toothcomb used for gouging, grooming and injecting venom; a unique posture, whereby the arms are clasped above the head, allowing the animal to combine brachial oil and saliva to produce venom; dark facial markings that are species specific

this case, an additional 6 to 8 mo was required to capture animals successfully, and numerous tagged animals were lost to the illegal medicine trade.

Many early surveys of slow lorises merely reported presence or count data (e.g. Fitch-Snyder \& Vu 2002). Nekaris et al. (2008) reviewed quantified survey re- sults until 2007 including survey data from 36 sites in Indonesia, Laos, India and Malaysia (see also Evans et al. 2000). Since then, numerous research groups have published their survey results, including results from India (Radhakrishna et al. 2006, 2010, Das et al. 2009, 2015, Nandini et al. 2009), Thailand (Pliosungnoen et al. 2010) and Cambodia (Starr et al. 2010a,b, Coudrat et al. 2011). Most of these surveys cover only single sites or a small number of sites within a restricted part of each respective species' range, thus leaving gaps in our knowledge of their distribution. Slow loris populations in several countries remain virtually unknown, and surveys of Bhutan, Bangladesh, China, Myanmar, Vietnam, the Philippines and the islands of Sumatra (Indonesia) and Borneo (Indonesia, Malaysia and Brunei) are urgently needed. Several questions remain unanswered, including where the range of the greater slow loris $N$. coucang ends and is replaced by the Bengal slow loris; which species of slow lorises are sympatric with each other and where; whether some of the populations that live isolated on the many islands (including some relatively large ones) represent distinct species and what their phylogenetic relationships with the other slow lorises are and what are realistic estimates of population sizes in the wild for each of the slow loris species.

\section{CURRENT KNOWLEDGE AND CONTRIBUTION OF THE THEME SECTION}

In this the section, contributors provide the first population data for slow lorises in several parts of their range. Voskamp et al. (2014, this Theme Section) found Javan slow lorises at 9 out of 14 sites across the island of Java. These authors not only increased the known range of the Javan slow loris Nycticebus javanicus to include eastern Java, but also found that this Critically Endangered species can persist in areas heavily dominated by humans, particularly agro- 
forests. Also on Java, Nekaris et al. (2014, this Theme Section) focused on a single area on Mount Gede Pangrango; they make recommendations on how to conduct further surveys, including taking into account the speed at which surveys are conducted as this factor can influence the number of animals seen. Munds et al. (2013a, this Theme Section) provide the first abundance estimates of Philippine slow lorises $N$. menagensis in Sabah, from the Lower Kinabatangan Wildlife Sanctuary. Along with reviewing the scanty abundance data available in areas where slow lorises and tarsiers (Tarsius) occur allopatrically or sympatrically, they conclude that competition may not only drive slow lorises to higher levels of the canopy when these genera occur in sympatry, but also that the abundance of tarsiers seems to decrease when the 2 genera are together. The poor visibility of nocturnal animals in the high Bornean canopy may explain why previous surveyors (Nekaris et al. 2008) had difficulty in detecting slow lorises there. Fam et al. (2014, this Theme Section) provide the first concerted effort to ascertain if wild slow lorises still occur in the island nation of Singapore. Despite field observations and collated data collected between 2008 and 2013, only 1 potential wild greater slow loris was seen, as well as an individual of the non-native pygmy loris, highlighting the concerns about the release of invasive species by people who no longer want the illegal animals as pets or by the authorities after the confiscation of such animals. All of these studies are first efforts to understand slow loris abundance and distribution, but they also show that slow loris species are not as widespread and abundant as previously assumed.

When trying to study a species for the first time in the wild, local people remain an excellent source of information to understand species distribution, ecology and how conservation programmes should be conducted. For example, Starr et al. (2010a) showed that local ecological knowledge of pygmy loris strongly corroborated ecological field data in eastern Cambodia. In the case of the nocturnal slow loris, they are often surrounded by myth and intrigue, are considered human-like or imp-like and are rarely seen (Nekaris et al. 2010). Svensson \& Friant (2014, this Theme Section) use local knowledge to examine the plight of slow lorises' African relatives, pottos and angwantibos. Despite all African lorisids currently considered Not Threatened according to IUCN threat criteria, Svensson \& Friant (2014) showed that they face parallel threats to those of Asian lorises, including their use in traditional medicine and as a non-targeted hunted animal. As with slow lorises, this incessant hunting means that animals are killed throughout the year, without respect to birthing or rearing seasons, as well as without respect to off-take, making them one of the most commonly hunted primates in parts of West Africa, just as slow lorises are in parts of Indochina (Starr et al. 2010a). Nijman \& Nekaris (2014, this Theme Section), who worked with 12 Sundanese communities in West Java, also use local knowledge to gain insight into the biology and conservation of slow lorises. They found that beliefs about slow lorises differ throughout the region, with some areas having taboos against catching them as pets, others having strong beliefs about the venomous properties of slow lorises and yet others seeing slow lorises as vital commodities. Nijman \& Nekaris (2014) suggested that such data, and understanding local differences in attitudes, are vital for establishing conservation projects. Local knowledge can also lead to intriguing hypotheses about the behavioural ecology of animals. In the case of slow lorises, just as has been shown for the poisonous pitohuis of New Guinea (Dumbacher et al. 2004), local people are very familiar with the unusual venomous nature of these primates, impacting their conservation.

Das et al. (2014, this Theme Section) also considered the ecology of Bengal slow lorises from the Gibbon Wildlife Sanctuary in Assam, northeast India, in light of local knowledge. Based on $>18$ mo of field data, they show that Bengal slow lorises predominantly consume exudates from 5 species of trees that are also used in local Ayurveda medicinal practices. They suggest that the association of Asian lorises with various medicinal plants may have been the starting point of the rampant use of slow lorises in traditional medicines in Asia (cf. Starr et al. 2010a). Their study also reaffirms the vital importance of exudates in the diet of slow lorises (Nekaris et al. 2010). Replicating an animal's natural diet in captivity is vital for its health; however, despite numerous studies providing irrefutable evidence that slow lorises are specialized exudate feeders, most captive facilities have not yet changed their traditional practices of feeding lorises a largely fruit-based diet. In their study, Cabana \& Plowman (2014, this Theme Section) show that by feeding pygmy lorises reared at a UK zoo a diet based on field evidence, abnormal behaviour decreased and desirable behaviours such as travelling and feeding increased, and that the study subjects found the naturalised diet far more palatable. Similarly Gray et al. (2015, this Theme Section) also examined exudate consumption in wild-caught slow lorises ( $N$. javanicus, $N$. coucang, $N$. menagensis) confiscated from the pet trade. Because of a destructive and cruel practice, whereby traders clip out the gouging teeth of slow 
lorises to prevent them from biting, many confiscated animals no longer have the faculty to gouge. Gray et al. (2015) thus trialled a series of gum-based enrichments also designed to suit animals that no longer had teeth. They found that the enrichment devices prolonged feeding and foraging times, and also gave the animals more opportunities to spend time off the floor, where they were more likely to exhibit stereotypic behaviours. Finally, Fuller et al. (2014, this Theme Section) reviewed $30 \mathrm{yr}$ of mortality data of pottos and slender and slow lorises in North American zoos. The taxonomy of lorisids in captivity has still not caught up with genetic and morphological assessments of the diversity within the Lorisidae (Nekaris 2014); it is thus not surprising that the majority of deaths in North American zoos were of neonates, which were likely to be hybrids between various species. Amongst older animals numerous pathologies occurred that again link back to a poor-quality diet in these animals, not excluding severe dental trauma (see also Streicher 2004). All of the above researchers point towards the extreme importance of consulting field data when attempting to keep animals in captivity. Further studies should examine if species-specific protocols are needed, or if a general captive regime is suitable across Nycticebus spp.

Understanding the behaviour of slow lorises is also vital when considering the fate of the many animals confiscated from the pet trade. The thought of reintroducing these animals back to wild habitats is appealing, but, until now, assessment of slow loris releases has been minimal (but see Streicher et al. 2003, Collins \& Nekaris 2008), and media reports indicate that hard releases of slow lorises are rampant. For example, the misconception that these animals are slow and solitary has led to their release in very small forest areas in large numbers, release with no monitoring, solitary release, release of nonendemic species, release into areas where no ecological assessment has been made, and/or release into areas where no health checks have been made of the releasees or of the wild slow lorises in the local area. Moore et al. (2014, this Theme Section) reviewed the difficult choices to be made when releasing slow lorises, and also provide data on survival rate from Javan and greater slow lorises from Indonesia. Similarly, Kenyon et al. (2014, this Theme Section) provided an overview of $2 \mathrm{yr}$ of releases of pygmy lorises in Vietnam. Both these studies showed the intensive amount of work needed for a reintroduction programme in terms of funds, manpower and time, yet both studies showed high death rates despite careful attendance to various aspects of the IUCN Guide- lines for Translocations (IUCN/SSC 2013). In both cases, at the time of the study, no data were available from wild populations of the species that were released, one of the most important suggestions made by the IUCN when releasing an animal to the wild. In northeast India, Kumar et al. (2014, this Theme Section) provide $>15 \mathrm{yr}$ of data of Bengal slow lorises confiscated from private gardens or from private owners. Their study shows that it is vital to understand the distribution of wild slow lorises. We now know that many slow loris populations live in home gardens; yet these animals were translocated with no follow up into an environment they had never known. For many years, slow lorises have not been considered priority species, and such 'mercy releases' have become common, yet are probably as deadly a threat as the trade itself; thus, understanding the rate at which this happens is the first step to halting such releases. We highly encourage that releases should follow recommended international protocols for release and that any organisation releasing lorises should report their successes as well as failures so that practices can be improved.

The 13 contributions in this Theme Section cover new field studies in 5 of the 13 countries in the range of slow lorises. We hope that this work will inspire researchers throughout Asia, as well as elsewhere, to help us further our understanding of slow loris taxonomy, geographic range, behaviour in the wild and the ever-increasing threats to their conservation. We encourage those interested in slow lorises to use similar methodologies to collect data, and to take advantage of the Internet to work together to share knowledge. Only after these factors are understood can we truly begin a conservation plan for these unique and threatened primates.

Acknowledgements. We thank all the authors of the papers who have contributed to this Theme Section of Endangered Species Research and the many reviewers who aided the process. We are grateful to Brendan Godley for accepting this topic as a Theme Section of the journal, and to Penny Kuhn for her invaluable help during the editing process. We thank A. Aldea, A. Gil-Vasquez and V. Nijman for their help in preparing the tables and figures. We thank A. Walmsley and M. Williams for providing the photographs. We thank Amersfoort Zoo, Augsburg Zoo, Blank Park Zoo, Brevard Zoo, Chicago Zoological Society/Chicago Board of Trade (CBOT) Endangered Species Fund, Cleveland Zoo and Zoo Society, Columbus Zoo, Henry Doorly Zoo, International Primate Protection League, Leverhulme Trust RPG-084, Memphis Zoo, Mohamed bin Zayed Species Conservation Fund, National Geographic, People's Trust for Endangered Species, Phoenix Zoo, Primate Action Fund, Primate Conservation Inc., Primate Society of Great Britain, Shaldon Wildlife Trust, Quantum Conservation Inc., ZACC and ZGAP for funding K. A. I. N.'s contributions to this Theme Section. 


\section{LITERATURE CITED}

Alterman L (1995) Toxins and toothcombs: potential allospecific chemical defenses in Nycticebus and Perodicticus. In: Alterman L, Doyle GA, Izard MK (eds) Creatures of the dark. Springer, New York, NY, p 413-424

Bandara R, Tisdell C (2005) Changing abundance of elephants and willingness to pay for their conservation. J Environ Manage 76:47-59

Barrett E (1981) The present distribution and status of the slow loris in peninsular Malaysia. Source Malaysian Applied Biology 10:205-211

- Cabana F, Plowman A (2014) Pygmy slow loris Nycticebus pygmaeus - natural diet replication in captivity. Endang Species Res 23:197-204

Cattau ME, Husson S, Cheyne SM (2014) Population status of the Bornean orang-utan Pongo pygmaeus in a vanishing forest in Indonesia: the former Mega Rice Project. Oryx, doi:10.1017/S003060531300104X

Collins R, Nekaris KAI (2008) Release of greater slow lorises (Nycticebus coucang), confiscated from the pet trade, to Batutegi Protected Forest, Sumatra, Indonesia. In: Soorae PS (ed) IUCN global re-introduction perspectives: re-introduction case studies from around the globe. IUCN/SSC Reintroduction Specialist Group, Abu Dhabi, p 192-195

> Coudrat CNZ, Rogers LD, Nekaris KAI (2011) Abundance of primates reveals Samkos Wildlife Sanctuary, Cardamom Mountains, Cambodia as a priority area for conservation. Oryx 45:427-434

Das N, Biswas J, Das J, Ray PC, Sangma A, Bhattacharjee PC (2009) Status of Bengal slow loris Nycticebus bengalensis (primates: Lorisidae) in Gibbon Wildlife Sanctuary, Assam, India. J Threat Taxa 1:558-561

Das N, Nekaris KAI, Bhattacharjee PC (2014) Medicinal plant exudativory by the Bengal slow loris Nyticebus bengalensis. Endang Species Res 23:149-157

> Das N, Nekaris KAI, Biswas J, Das J, Bhattacharjee PC (2015) Persistence and protection of the Vulnerable Bengal slow loris Nycticebus bengalensis in Assam and Arunachal Pradesh, north-east India. Oryx 49:127-132

Dietz JM, Dietz LA, Nagagata EY (1994) The effective use of flagship species for conservation of biodiversity: the example of lion tamarins in Brazil. In: Mace GM, Feistner ATC, Olney PJ (eds) Conservation: interactive management of wild and captive populations. Chapman \& Hall, London, p 32-49

> Dumbacher JP, Wako A, Derrickson SR, Samuelson A, Spande TF, Daly JW (2004) Melyrid beetles (Choresine): a putative source for the batrachotoxin alkaloids found in poison-dart frogs and toxic passerine birds. Proc Natl Acad Sci USA 101:15857-15860

- Evans TD, Duckworth JW, Timmins RJ (2000) Field observations of larger mammals in Laos, 1994-1995. Mammalia 64:55-100

Fam SD, Lee BPYH, Shekelle M (2014) The conservation status of slow lorises Nycticebus spp. in Singapore. Endang Species Res 25:69-77

Fitch-Snyder H, Vu NT (2002) A preliminary survey of lorises (Nycticebus spp.) in northern Vietnam. Asian Primates 8:1-3

Fuller G, Lukas KE, Kuhar C, Dennis PM (2014) A retrospective review of mortality in lorises and pottos in North American zoos, 1980-2010. Endang Species Res 23: 205-217
> Gray A, Wirdateti, Nekaris KAI (2015) Trialling exudatebased enrichment efforts to improve the welfare of rescued slow lorises Nycticebus spp. Endang Spec Res $27: 21-29$

Groves CP (2001) Primate taxonomy. Smithsonian Institute Press, Washington, DC

> Grow NB, Wirdateti, Nekaris KAI (2015) Does toxic defence in Nycticebus spp. relate to ectoparasites? The lethal effects of slow loris venom on arthropods. Toxicon 95:1-5

Ishida H, Hirasaki E, Matano S (1992) Locomotion of the slow loris between discontinuous substrates. In: Matano $\mathrm{S}$, Tuttle RH, Ishida H, Goodman M (eds) Topics in primatology, Vol 3. Evolutionary biology, reproductive endocrinology, and virology. University of Tokyo Press, Tokyo, p 139-152

IUCN/SSC (International Union for the Conservation of Nature/Species Survival Commission) (2013) Guidelines for re-introductions and other conservation translocations (Version 1.0). IUCN/SSC, Gland

Kenyon M, Streicher U, Loung H, Tran T, Tran M, Vo B, Cronin A (2014) Survival of reintroduced pygmy slow loris Nycticebus pygmaeus in South Vietnam. Endang Species Res 25:185-195

Kingston AK, Boyer DM, Patel BA, Larson SG, Stern JT Jr (2010) Hallucal grasping in Nycticebus coucang: further implications for the functional significance of a large peroneal process. J Hum Evol 58:33-42

Kumar A, Sarma K, Panvor J, Mazumdar K, Devi A, Krishna M, Ray PC (2014) Threats to the Bengal slow loris Nycticebus bengalensis in and around Itanagar Wildlife Sanctuary, Arunachal Pradesh, India: impediments to conservation. Endang Species Res 23:99-106

Leader-Williams N, Dublin HT (2000) Charismatic megafauna as flagship species. In: Entwistle A, Dunstone N (eds) A review of priorities for the conservation of mammalian diversity: Has the panda had its day? Cambridge University Press, Cambridge, p 53-81

- Moore RS, Wihermanto, Nekaris KAI (2014) Compassionate conservation, rehabilitation and translocation of Indonesian slow lorises. Endang Species Res 26:93-102

> Munds RA, Ali R, Nijman V, Nekaris KAI, Goossens B (2013a) Living together in the night: abundance and habitat use of sympatric and allopatric populations of slow lorises and tarsiers. Endang Species Res 22:269-277

> Munds RA, Nekaris KAI, Ford SM (2013b) Taxonomy of the Bornean slow loris, with new species Nycticebus kayan (primates, Lorisidae). Am J Primatol 75:46-56

Nandini R, Kakati K, Ved N (2009) Occurrence records of the Bengal slow loris (Nycticebus bengalensis) in northeastern India. Asian Primates J 1:12-18

Nekaris KAI (2006) Social lives of adult Mysore slender lorises (Loris lydekkerianus lydekkerianus). Am J Primatol 68:1171-1182

Nekaris KAI (2014) Extreme primates: ecology and evolution of Asian lorises. Evol Anthropol 23:177-187

Nekaris KAI, Bearder SK (2007) The strepsirrhine primates of Asia and mainland Africa: diversity shrouded in darkness. In: Campbell C, Fuentes A, MacKinnon K, Panger M, Bearder SK (eds) Primates in perspective. Oxford University Press, Oxford, p 24-45

> Nekaris KAI, Campbell N (2012) Media attention promotes conservation of threatened Asian slow lorises. Oryx 46: 169-170

Nekaris KAI, Jaffe S (2007) Unexpected diversity of slow lorises (Nycticebus spp.) within the Javan pet trade: 
implications for slow loris taxonomy. Contrib Zool 76: 187-196

Nekaris KAI, Nijman V (2007) CITES proposal highlights rarity of Asian nocturnal primates (Lorisidae: Nycticebus). Folia Primatol (Basel) 78:211-214

Nekaris KAI, Blackham GV, Nijman V (2008) Conservation implications of low encounter rates of five nocturnal primate species (Nycticebus spp.) in Asia. Biodivers Conserv 17:733-747

Nekaris KAI, Starr C, Collins RL, Navarro-Montes A (2010) Comparative ecology of exudate feeding by lorises ( $\mathrm{NyC}$ ticebus, Loris) and pottos (Perodicticus, Arctocebus). In: Burrows A, Nash L (eds) The evolution of exudativory in primates. Springer, New York, NY, p 155-168

Nekaris KAI, Campbell N, Coggins TG, Rode EJ, Nijman V (2013a) Tickled to death: analysing public perceptions of 'cute' videos of threatened species (slow lorises-Nycticebus spp.) on Web 2.0 sites. PLoS ONE 8:e69215

Nekaris KAI, Moore RS, Rode EJ, Fry BG (2013b) Mad, bad and dangerous to know: the biochemistry, ecology and evolution of slow loris venom. J Venom Animals Tox inc Trop Dis 19:21, doi:10.1186/1678-9199-19-21

Nekaris KAI, Shekelle M, Wirdateti, Rode EJ, Nijman V (2013c) Nycticebus javanicus. The IUCN Red List of Threatened Species, Version 2014.3. Available at: www.iucnredlist.org (accessed 1 February 2015)

> Nekaris KAI, Pambudi JAA, Susanto D, Ahmad RD, Nijman V (2014) Densities, distribution and detectability of a small nocturnal primate (Javan slow loris Nycticebus javanicus) in a montane rainforest. Endang Species Res 24:95-103

Nijman V, Nekaris KAI (2010) Checkerboard patterns, interspecific competition and extinction: lessons from distribution patterns of tarsiers and slow lorises in insular Southeast Asia. Int J Primatol 31:1147-1160

> Nijman V, Nekaris KAI (2014) Traditions, taboos and trade in slow lorises in Sundanese communities in southern Java, Indonesia. Endang Species Res 25:79-88

Nijman V, Shepherd CR (2015) Trade in tigers and other wild cats in Mong La and Tachilek, Myanmar-a tale of two border towns. Biol Conserv 182:1-7

Nijman V, Shepherd C, Nekaris KAI (2014) Trade in Bengal slow lorises in Mong La, Myanmar, on the China Border. Primate Conserv 28:139-142

Pimley ER, Bearder SK, Dixson AF (2005) Examining the social organization of the Milne-Edward's potto Perodicticus potto edwardsi. Am J Primatol 66:317-330

> Pliosungnoen M, Gale G, Savini T (2010) Density and microhabitat use of Bengal slow loris in primary forest and non-native plantation forest. Am $J$ Primatol 72: 1108-1117

Pozzi L, Hodgson JA, Burrell AS, Sterner KN, Raaum RL, Disotell TR (2014) Primate phylogenetic relationships and divergence dates inferred from complete mitochondrial genomes. Mol Phylogenet Evol 75: 165-183

Radhakrishna S, Goswami BA, Sinha A (2006) Distribution and conservation of Nycticebus bengalensis in northeastern India. Int J Primatol 27:971-982

Radhakrishna S, Datta-Roy A, Swapna N, Sinha A (2010) Population survey of the Bengal slow loris, Nycticebus bengalensis, in Meghalaya, Northeast India. Primate Cons 25:105-110

Rode-Margono EJ, Nekaris KAI (2014) Impact of climate and moonlight on a venomous mammal, the Javan slow loris (Nycticebus javanicus). Contrib Zool 83:217-225

Rogers LD, Nekaris KAI (2011) Behaviour and habitat use of the Bengal slow loris (Nycticebus bengalensis) in grasslands of Samkos Wildlife Sanctuary, Cambodia. Camb J Nat His 2:104-113, www.fauna-flora.org/publications/ cambodian-journal-of natural history/

Schulze H, Groves CP (2004) Asian lorises: taxonomic problems caused by illegal trade. In: Nadler T, Streicher U, Thang Long $\mathrm{H}$ (eds) Conservation of primates in Vietnam. Frankfurt Zoological Society, Frankfurt, p 33-36

> Sellers WI (1996) A biomechanical investigation into the absence of leaping in the locomotor repertoire of the slender loris (Loris tardigradus). Folia Primatol (Basel) 67:1-14

Shepherd CR, Sukumaran J, Wich SA (2005) Open season: an analysis of the pet trade in Medan, North Sumatra, 1997-2001. TRAFFIC Southeast Asia, Petaling Jaya

Sodhi NS, Posa MRC, Lee TM, Bickford D, Koh LP, Brook BW (2010) The state and conservation of Southeast Asian biodiversity. Biodivers Conserv 19:317-328

> Starr C, Nekaris KAI (2013) Obligate exudativory characterizes the diet of the pygmy slow loris Nycticebus pygmaeus. Am J Primatol 75:1054-1061

Starr C, Nekaris KAI, Streicher U, Leung L (2010a) Traditional use of slow lorises Nycticebus bengalensis and $N$. pygmaeus in Cambodia: an impediment to their conservation. Endang Species Res 12:17-23

Starr CR, Nekaris KAI, Rogers LD, Streicher U (2010b) Surveys and preliminary field observations of the northern slow loris (Nycticebus bengalensis) in Cambodia. In: Nadler T, Rawson B (eds) Conservation of primates of Indochina. Springer, New York, NY, p 43-52

Streicher U (2004) Aspects of ecology and conservation of the pygmy loris Nycticebus pygmaeus in Vietnam. PhD dissertation, Ludwig Maximilian University, Munich

Streicher U, Nadler T, Zinner D (2003) Re-introduction study of pygmy lorises in Vietnam. Re-intro Newsl 23:37-40

Streicher U, Collins R, Wilson A, Nekaris KAI (2012) Observations on the feeding preferences of slow lorises $(N$. pygmaeus, N. javanicus, N. coucang) confiscated from the trade. In: Masters J, Gamba M, Genin F (eds) Leaping ahead: advances in prosimian biology. Springer, New York, NY, p 165-172

Svensson MS, Friant SC (2014) Threats from trading and hunting of pottos and angwantibos in Africa resemble those faced by slow lorises in Asia. Endang Species Res 23:107-114

Swapna N, Radhakrishna S, Gupta AK, Kumar A (2010) Exudativory in the Bengal slow loris (Nycticebus bengalensis) in Trishna Wildlife Sanctuary, Tripura, northeast India. Am J Primatol 72:113-121

- Voskamp A, Rode EJ, Coudrat CNZ, Wirdateti, Abinawanto, Wilson RJ, Nekaris KAI (2014) Modelling the habitat use and distribution of the threatened Javan slow loris $\mathrm{NyC}$ ticebus javanicus. Endang Species Res 23:277-286

Wiens F (2002) Behavior and ecology of wild slow lorises (Nycticebus coucang): social organisation, infant care system and diet. PhD thesis, Bayreuth University, Bayreuth

Wittemyer G, Northrup JM, Blanc J, Douglas-Hamilton I, Omondi P, Burnham KP (2014) Illegal killing for ivory drives global decline in African elephants. Proc Natl Acad Sci USA 111:13117-13121

Submitted: February 4, 2015; Accepted: March 2, 2015

Proofs received from author(s): June 3, 2015
Editorial responsibility: Brendan Godley,

University of Exeter, Cornwall Campus, UK 